\title{
Modeling the growth and policy implications of Global System for Mobile Telecommunication (GSM) in Nigeria
}

\author{
Bakare Adewale Stephen \\ (Department of Economics, Adekunle Ajasin University, P.M.B 001, Nigeria)
}

\begin{abstract}
This paper investigated the growth and policy implications of Global System for Mobile Communication in Nigeria. Stochastic economic modeling was used to analyze Nigeria's time series data. The models were adjudged reliable before they were used. The components of the model were defined and a prior expectation of the relationship among the variables explained for the purpose of giving the reviewers and users a deep insight into the phenomenon under study. The secondary data used for the study were processed using the E-View for windows electronic packages. The outcome of the empirical and stochastic investigations shows that Global System for Mobile Communication has a positive relationship with output growth in Nigeria. The impact is of a higher magnitude. The usage of Global System for Mobile Telecommunication led to 17 percent rise in the output growth. The findings suggest the need for the Nigerian Communication Commission (NCC) and the federal government of Nigeria to expand tele-density and directly make telephone communications cheap and accessible. To achieve this goal, more licenses should be given to GSM operators in order to allow for healthy competition among them. This will lead to improved quality of services, quality of product and consequently sustain the growth and development of the country.
\end{abstract}

Key words: Global System for Mobile Communication (GSM); tele-density; economic growth; deregulation

\section{Introduction}

Up till year 1998, telecommunication was under government control in Nigeria. The government considered it to be so vital to national interest and treat it as a public good that can only be owned and distributed by it. This monopoly and government regulation affected the aggregate supply and hence made the aggregate demand to overshoot supply. Thus the cost of owning a telephone line was very high and only very few Nigerians can afford it. Consequently, Nigeria, maintained an unenviable record as the world's third lowest user of telephone, after Mongolia and Afghanistan, with a tele-density of 0.73 percent. This was far below the world minimum tele-density (number of telephone lines in relation to population) (Okereocha, 2008). The nation's telecoms were liberated with the return of democracy in 1999. The deregulation of the telecoms sector, which had earlier begun in 1992, took a revolutionary dimension in 2001 with the granting of the Global System for Mobile Telecommunication (GSM) license by the Nigerian Communication Commission (NCC) to three providers: Econet/Celtel now Zain, MTN and M-tel. This was followed by the licensing of the second national operator (SNO), in 2003, that is, Globalcom and Universal access service licenses in 2006 which include fixed telephony, VSAT and internet service providers. Also, in March 2008, the NCC gave license to another GSM operator known

Bakare Adewale Stephen, Ph.D., senior lecturer, Department of Economics, Adekunle Ajasin University; research fields: development economics and international finance. 
as Etisalat (Aigbinode, 2008). This made the GSM subscribers in Nigeria to be able to make and receive calls, receive and send SMS, forward calls and bar calls and other enhanced supplementary services, among which were Calling Line Identify (CLI), call waiting, Multi-Party Services, MMS (Multi Media Services), General Packet Radio Services (GPRS) for accessing the internet, and also High Speed Circuit Switched Data (HSCSD). This phenomenon has resulted in a dramatic increase in the total number of lines which stood at 866,782 in 1999, to over 60 million lines in 2008, out which GSM operators accounted for 57,622,901 lines and fixed land line operators accounted for 2,537,504 (Ndukwe, 2008). This recent drive in telecom reform policy initiatives in Nigeria has made telecom an engine of economic growth and development. It has become an important vehicle in permitting information exchange to develop as a valuable commodity for moving the country into post industrial and information based economy. In this present world, a modern telecommunications infrastructural development is not only essential for domestic economic growth, but also a prerequisite for participation in increasingly competitive world markets and for attracting new investments.

Given this development, the perspective on telecommunications development research today should concentrate on how best to increase and include telecommunication as an essential component of the economic development. Telecommunication infrastructural development should indeed be seen as an indispensable precedent in economic development, and according to World Bank analysts, late starters in the telecommunications, "will risk exclusion from the global economy and face severe competitive disadvantage on their goods and services" (World Bank, 1995).

This indicates that good telecommunication development is an important input for economic success in the modern world both on a microeconomic and macroeconomic scale. Today, telecommunication particularly GSM (Global System for Mobile Communication) is the fastest growing technology of all time. In 2006, estimates place the telecommunication industry's revenue at $\$ 1.2$ trillion dollars.

The recognition that telecommunications development is an important input in a household or a nation's production function should also have major implication for development policy. Ten years ago, it may have been argued, as did Rowland in Mazango (1998), that telecommunications development policy and research was still in its teething stages. It is instructive, however, to find out the extent and the magnitude of the impact of policy implications of Global System for Mobile Communication on the growth of Nigeria economy. This is built on the premise that Global System for Mobile Communication has not received a great deal of attention from researchers. It is against this background that this study has been conceived and inspired. But the questions to ask for which answers shall be sought are: (1) has Global System for Mobile Communication achieved its stated advantages? (2) Has it encouraged competition locally and internationally with the new trend of globalization? (3) Has it strengthened the industrialization and stimulated the growth of Nigerian economy? This study seeks to research these questions and provide answers to them. The rest of this paper is organized as follow: In section 2, the author reviews the literatures covering the trends, importance, growth and policy implications of Global System for Mobile Communication in Nigeria. In section 3, the author briefly introduces and discusses the research methodology. Section 4 is dedicated to data analysis, interpretation of result and discussions. Section 5 summarizes the findings, draws policy recommendations and concludes the paper.

\section{Literature review}

Early work on economic growth and development highlighted the necessity of adequate infrastructure as a 
basis for development. Hirschman (1958), for example, recognized the importance of social over head capital which he defined as those services without which primary, secondary and tertiary production activities cannot function. The social over head capital includes all public services from law and order through education and public health to transportation, communications, power and water supply.

According to Belaid (2002), fewer studies focus on specific telecommunications infrastructure and their roles in economic performance. The main ones concentrate on a contribution of telecommunications in reducing transaction cost, increasing total factor productivity (TFP) of the private sector and diffusion of new technologies which will remedy the problem of the developing countries. To Star and Bowker (2001), infrastructure is embedded within other structures and technologies, and it is transparent in use, not needing to be reinvented at each use and only becoming evident when it breaks down. As for Rickets (2002), telecommunications, by aiding the coordination of information flow, provides opportunities for increasing the efficiency of interaction and coordination, and in this manner impacts the success of economic activities. Economic activities require significant levels of interaction and coordination in order for them to be conducted successfully and efficiently. Interaction and coordination in turn require considerable amounts and different types of information; and as such, information needs and the mechanisms of satisfying those needs are key factors that drive the structuring of economic activity.

To Alleman, Rappoport and Taylor (2004), a modern telecommunication infrastructure is not only essential for domestic economic growth, but a prerequisite for participating in increasingly completive world markets and for attracting new investments. Telecoms have been considered an essential factor of production for the output of a country, and both catalyst and product of economic growth. Governments and private agencies in both developed and less develop countries spend large sums of capital on infrastructure investment so as to positively influence economic activities in terms of employment, value added, productivity, capital formation and income.

According to Alleman, Rappoport and Taylor (2004), investing in telecommunication like other infrastructure investments will increase the demand for the goods and services used in their production and increase total national output. And most telecoms investment positively affects economy in three ways:

First, it reduces the cost of production;

Second, it increases revenue;

Third, it increases employment through both direct and indirect effects.

To the contrary, Sinha (1995) argued that economic incentives for network expansion drive network development in the most economically attractive segments of the market to the detriment of "unprofitable" areas and particular affect access equality. The skewed network distribution that results, which can be either vertical (leading to class based access inequality), or horizontal (leading to regional access inequality), or some combination of both, undermines the potential country-wide benefit of telecoms.

Vuong (2008), reported how mobile phones promotes economic growth through an example of fishermen in the South of Indian by communicating through mobile phones, they were able to sell their fish on markets where the demand was high. This resulted in less waste of fish, higher benefits and lower cost of doing business, more access to information which leads to more efficient operations which in the end effect the economic growth. Also, Roller and Waverman (2001), Waverman, Meshi and Fuss (2005), in their study on telecoms, opined that telecoms infrastructure can lead to economic growth through many different ways. Firstly, according to them, investing in the telecom sector itself leads to growth. The increased demand in telecom related goods and services (e.g., producing cables, machines and extra workloads already contributes to growth). More importantly, as telephone 
technology improves, people communicated more regularly over bigger distances. Having more advanced telephone systems reduce individual and firms costs of doing business, it lowers costs of search etc. All these lead to more efficient operations in different economic sector.

Telecommunications has impact on Human and social capital. Debraj (1998) explored issues of economic development, through history, theory and growth in the developing world in development economics. He examined new growth theories which incorporate human capital into the economic equations used to measure material achievements and productivity. Human capital is a term, which includes education, skills and human capabilities that enhance production. Human capital can be translated into measures for inclusion in economic equations. Social capital is a term for valuing the benefits of human communication, and can also be translated into measures for incorporation in economic analysis. According to Widner and Mundt (1998) human relationship grows ever more dependent on mediating technologies, when human communication processes are exposed to and have regular access to them.

A large number of studies of the demand for telephone services have focused on estimating the price and income elasticities of demand for telephone services. Gyimah-Brempong and Karikari (2002) and Karikari and Gyimah-Brempong (1999), investigated the demand for international telephone calls between the US and Africa and found low price and income elasticities in both the short run and long run. Trotter (1996), Agiakloglou and Yannelis (2006), Lurdes and Martins (2003) and Garen-Munoz and Perez-Amaral (1998), investigated the demand for long distance phone calls and found that demand is influenced by price of telephone calls, income and network effects. The estimated price and income elasticities are generally less than unity (Gyimah-Brempong \& Karikari, 2007).

In recent years, there have been a large number of telephone demand studies that emphasize the substitution or complementary between fixed and mobile telephone services. While some of these studies found substitution between mobile phones and fixed phones systems using consumer phone data (Rodini, Ward \& Woroch, 2003; Vagliasindi, Guney \& Taubman 2006; Madden \& Coble-Neal, 1999; Okada \& Hatta, 1999), others found that mobile phones and fixed phones are moderate substitutes. Vagliasindi, Guney and Taubman (2006) found that the lower the penetration rates of fixed phones, the stronger the substitutability between fixed and mobile phones, all things been equal. This may be similar to the African situation (including Nigeria) since telephone penetration rates are low in Africa compared to other parts of the world. These studies found substantial cross-price elasticity. In addition to price, substitution between fixed and mobile phones is also influenced by capacity constraints of fixed lines (Minges, 1999) as well as network externalities (Doganoglu \& Grzybowski, 2007). It is therefore, interesting to note that telecoms infrastructure has strong potential for economic growth, especially for a developing country like Nigeria.

In summary, there are three major strands of views on the links between telecommunication and economic growth and development. The first strand considered the implication of telecom development on foreign direct investment. The main contribution of these studies was in determining the role of telecom in reducing transaction cost, increasing TFP (total factor productivity) of the private sector and diffusion of new technologies, which will remedy the problem of the developing countries and then lead to economic growth (Belaid, 2002). The second strand of studies examined the impact of telecom on overall macroeconomic performance by examining the effect of telecom development on economic growth, income generation of government and fiscal performance (Alleman, Rappoport \& Taylor, 2004). The last strand of studies is devoted to the examination of the impact of telecom development on rural development and poverty reduction. The bulk of these studies were not carried out in sub-Sahara African countries, but rather, in Asia and Latin American countries. 
The pertinent research issue that emanates from the forgoing is that there are scanty empirical studies in this area in Nigeria, hence the need to carry out empirical investigations on the growth and policy implications of Global System for Mobile Communication in Nigeria. This study fills this gap. In further research, the author shall look at the impacts of mobile communication on income and employment generation and transaction cost.

\section{Methodology of the study}

This section discusses the methodology and theoretical significance of the study. Issues relating to the choice of research design and strategies, model specification, data requirements and sources, the nature and scope of data collected, the data processing technique and the theoretical significance of parameter estimate are discussed. The models were adjudged reliable before they were used. The components of the model were defined, and a priori expectations of the relationship among the variables explained for the purpose of giving the reviewers and users a deep insight into the phenomenon under study.

\subsection{Research design and strategies}

The study uses quasi-experimental research design approach for the data analysis. This approach combines theoretical consideration (a prior criterion) with the empirical observation and extracts maximum information from the available data. It enables us, therefore, to observe the effects of explanatory variables on the dependent variables.

\subsection{Data requirement and sources}

Given the nature of the model, it is imperative that the data that will permit the estimation of the stochastic equations representing the implications of bank recapitalization on bank performances and economic growth can be collected. These include: gross domestic output growth rate, GSM Tele-density and GSM connected lines. Time series data were used for the study. The data were obtained from Central Bank of Nigeria (CBN) annual statistical bulletin and National Bureau for Statistics (NBS).

\subsection{Data processing techniques}

The secondary data used for the study were processed using the e-view for windows electronic packages. These packages are suitable because they are time efficient in terms of output and adequacy of statistics generated. The empirical study uses a simulation approach to investigate the relationship between the economic growth and global system for mobile communication. The e-view econometric package also helps to determine the long run relationship among the dependent and independent variables.

\subsection{Model specification}

The main question or hypothesis being addressed in this empirical analysis is whether or not the global system for mobile communication has positive and significant impact on the output growth in Nigeria. Consequently, the growth model is specified mathematically as:

$$
\text { GDP }=\text { F (TELED, LGSM) }
$$

This can be expressed in a linear form as:

$$
\text { GDP }=\Phi_{0}+\Phi_{1} \text { TELED }+\Phi_{2} \text { LGSM }
$$

If we include the error term, equation (2) can be rewritten as:

$$
\text { GDP }=\Phi_{0}+\Phi_{0}+\Phi_{1} \text { TELED }+\Phi_{2} \text { LGSM }+\mathrm{U}_{\mathrm{i}}
$$

where,

$G D P=$ Gross Domestic Product;

$T E L E D=$ GSM Tele-Density; 
$L G S M=\mathrm{GSM}$ connected lines;

$\Phi_{0}=$ constant Factor;

$\Phi_{1}, \ldots, \Phi_{n}=$ slopes of the variables for estimation;

$U_{i}=$ Error term.

On theoretical ground, (a priori) we expect the parameters to take positive signs, i.e., $\Phi_{l}, \Phi_{2}>0$. This mean there should be positive relationship between GDP growth rate, GSM Tele-density and GSM connected lines.

\section{Regression results and discussions}

The output of the regression is given in Table 1. The data period is from 2001 to 2008. This was the most appropriate period as GSM started effectively in Nigeria in 2001, and data on 2009 and 2010 are still unavailable. The result of the regression as reported in the table shows that both the GSM connected lines (GSM) and Tele-density (TELED) are significant and affect gross domestic output (GDP).

(1) The coefficient of the multiple determination $R^{2}$ : The coefficient of the multiple determination stood at 0.979604 (i.e., 97\%). This means that the explanatory variables: GSM tele-density and GSM connected lines accounted for $97 \%$ of the total changes in the dependent variable (GDP). This is a good fit.

Table 1 Regression results on effect of GSM on the growth of Nigerian economy

\begin{tabular}{|c|c|c|c|c|}
\hline Variable & Coefficient & Std. Error & $t$-Statistic & Prob. \\
\hline $\mathrm{C}$ & 10.55028 & 0.339110 & 31.11165 & 0.0000 \\
\hline LGSM & 0.165212 & 0.023346 & 7.076657 & 0.0009 \\
\hline TELED & -0.004021 & 0.002822 & -1.425070 & 0.2135 \\
\hline$R$-squared & 0.985432 & \multicolumn{2}{|c|}{ Mean dependent } & 13.16703 \\
\hline Adjusted $R$-squared & 0.979604 & \multicolumn{2}{|c|}{ S.D. dependent var } & 0.211796 \\
\hline S.E. of regression & 0.030247 & \multicolumn{2}{|c|}{ Akaike info riterion } & 878829 \\
\hline Sum squared resid & 0.004574 & \multicolumn{2}{|c|}{ Schwarz criterion } & -849038 \\
\hline Log likelihood & 18.51531 & \multicolumn{2}{|c|}{$F$-statistic } & 169.1061 \\
\hline Durbin-Watson stat & 1.536237 & \multicolumn{2}{|c|}{$\operatorname{Prob}(F$-statistic) } & 0.000026 \\
\hline
\end{tabular}

Notes: Dependent variable: LGDP; Method: least squares; Date: 05/18/10, time: 16:41; Sample: 2001-2008; Included observations: 8 .

Data source: Data analysis, 2010.

(2) The standard error: The value of the standard error for the entire variables in the model shows that the parameter estimate was statistically significant. These values were less than half of the values of the coefficient of the variables.

(3) Durbin-Watson statistics: The test for the presence of autocorrelation was performed by making use of the Durbin Watson statistics. The Durbin-Watson statistics is 1.5. This was found to be within the normal region which falls within the determined region (i.e., $1.5<\mathrm{d}<4$ ) and imply that there is negative first order serial autocorrelation among the explanatory variables.

(4) The GSM lines variable: The GSM lines variable was correctly and positively signed. It was also statistically significant. The expected outcome of this coefficient is a positive one. The implication of this result is that, if GSM lines increases in the long-run, all other things being equal, the economy will grow. It shows that a 1 percent rise in GSM lines will cause as much as 17 percent growth in the gross domestic output. This result indicated that GSM lines have the greater influence on the growth of Nigerian economy. From economic point of views, if GSM lines increases, it would reduce the cost of business such as cost on mobility and travelling as well 
as transaction cost. This reduction in cost would boost investment and promote more production of goods and services. It could also result in increase in efficiency. When one considered the nature of Nigerian road or other means of transport, one would realise that the introduction of GSM might have reduced the number of travels and reduce the fatigue and time wasted on the road networks across the country. So as the number of GSM lines increases there are tendencies for the economy's productive capacity to be boosted.

(5) With respect to the tele-density, contrary to expectation, the sign is negative but significant. Higher density implies that the higher number of people has access to telephone. As the density reduces the telephone lines per 1000 person reduces and fewer people have access to telephone. The implication of these results is that Tele-density is still very low to permit an overall increase in output growth in Nigeria.

\section{Summary of findings, conclusions and policy recommendations}

\subsection{Summary of findings}

This paper investigated the growth and policy implications of Global System for Mobile Communication in Nigeria. Stochastic economic model was used on Nigeria's time series data. The findings can be summarized as follows:

(1) The study carried out comprehensive literature reviews and found that there was a scanty empirical study in this area, particularly in sub-Sahara Africa including Nigeria.

(2) It was discovered that the licensing of digital mobile operators in 1999 was perhaps the most successful and applauded licensing process in the history of public sector deregulations in Nigeria. It was certainly the most visible transparent licensing and deregulation process. Both the successful participants and the failed bidders accepted the process as largely free of government manipulation and interaction.

(3) The Nigerian economy is predicted to have naturally gained from emerging into information technology age. Meanwhile, a licensing process universally adjudges to have been rare display of transparency, openness and non-intervention, has turned the fortunes of the country around, and consequently raises investor's confidence in the Nigerian market and economy.

(4) The outcome of the empirical and stochastic investigations shows that Global System for Mobile Communication has a positive relationship with output growth in Nigeria. The impact is of a higher magnitude. The introduction of Global System for Mobile Telecommunication led to 17 percent rise in the output growth.

(5) The author discovers that if the Tele-density should increase to a considerable level in Nigeria, there would be industrial and technological transformation and the growth and development of Nigeria economy would be sustained.

\subsection{Conclusion}

The Global System for Mobile Telecommunication to our findings is a stimulant to economic growth of any country including Nigeria. It is an effective instrument that can be used to achieve sustainable growth and development. But for the Global System for Mobile Telecommunication to achieve this noble goal, a more competitive economic system through greater deregulation should be pursed. The author's conclusion therefore is that the existence of Global System for Mobile Telecommunication is good and can be regarded as a breakthrough for Nigerian economy.

\subsection{Policy recommendations}

From the findings and conclusions presented above, the following policy recommendations could be made to 
the regulatory body of GSM in Nigeria, that is, the Nigerian Communication Commission (NCC) and the federal government of Nigeria. The government should expand tele-density and directly make telephone communications cheap and accessible. To achieve this goal, more licenses should be given to GSM operators in order to allow for healthy competition among the GSM operators. This will lead to improved quality of services, quality of product and consequently increased employment creation in the country.

Therefore, there is need for the federal government to provide the necessary telephone infrastructure (particularly power supply) to the GSM operators in order for them to deliver efficient services and to be able to reduce their call charges.

Moreover, the Nigerian Communication Commission should create a regulatory environment for the supply of telecommunication services and facilities and the promotion of fair competition and efficient market conduct for all partakers. Also, the NCC should establish technical norms and promote the development of Nigeria telecommunications capabilities, industries and skills.

\section{References:}

Agiakloglou, C. \& Yannelis, D.. (2006). Estimation of price elasticities for international telecommunications demand. International Advances in Economic Research, 12, 131-137.

Aigbinode, R.. (2008). Seven years of telecoms revolution-The breathtaking revolution in telecoms industry. Tell Magazine of Nigeria, 7.

Alleman, J. C., et al. (2004). Telecommunications and economic development: Empirical evidence from southern Africa. International Telecommunications Society, Sydney. Retrieved from http://www.colorado.edu/engineering /alleman/print_files/soafrica_paper. pdf.

Doganoglu, T. \& Grzybowski, L.. (2007). Estimating network effects in mobile telephony in Germany. Information Economics and Policy, 19, 65-79.

Garin-Munoz, T., Perez-Amaral, T.. (1998). Economic modeling of Spanish very long distance international calling. Information Economics and Policy, 10, 237-252.

Gyimah-Brempong, K. \& John, A. K.. (2007). Telephone demand and economic growth in Africa. OECD Economic Studies, 38(1).

Hend, B.. (2002). Telecommunication infrastructural and economic development, simultaneous approach: Case of developing countries. ERMES, Research Team on Markets, Employment and Simulation, Paris II University, Pantheon-Assas.

Lurdes, M. \& Martins, C.. (2003). International differences in telecommunications demand. Information Economics and Policy, 15, 291-303.

Mazango, E.. (1998). Telecommunications sector reform: Liberalization and universal service policy in Zimbabwe. (Doctoral dissertation, IMK, University, Oslo)

Minges, M.. (1999). Mobile cellular communications in the southern African region. Telecommunications Policy, 23, $585-593$.

Okereocha, C.. (2008). Seven years of telecoms revolution-One revolution, a thousand gains. Tell Magazine of Nigeria, 7.

Pancucci, D.. (1995). Remote control. Management Today, 4, 78.

Petrazzini, B. A.. (1995). The socioeconomic impact of reform. In: The political economy of telecommunications reform in developing countries: Privatization and liberalization in comparative perspective. US: Westport, Conn.: Praeger, 165-189.

Ricketts, M.. (2002). The economics of business enterprise. UK: Cheltenham: Edward Elgar.

Rodini, M., Ward, M. \& Woroch, G.. (2003). Going mobile: Substitutability between fixed and mobile access. Telecommunications Policy, 27, 457-476.

Star, S. \& Bowker, G.. (2001). How to develop infrastructure. In: Lievrouw, L. A. \& Livingstone, S. (Eds.), The handbook of new media. London: Thousand Oaks, New Delhi.

Trotter, S.. (1996). The demand for telephone services. Applied Economics, 28, 175-184.

Vagliasindi, M., Guney, I. \& Taubman, C.. (2006). Fixed and mobile competition in transition economies. Telecommunications Policy, $30,349-367$

Vuong, V.. (2008, May). Mobile telecommunication impact on developing countries growth. Bachelor Thesis of International Economics and Finance, Tilburg University.

Waverman, L., Meshi, M. \& Melvyn, F.. (2005). The impact of telecoms on economic growth in developing countries. Vodafone Policy Paper, series No. 2, 10-24.

Wilson, K.. (1992). Deregulating telecommunications and the problem of natural monopoly: A critique of economics in telecommunication policy. Media, Culture \& Society, 14, London: Sage Publications, 343-368.

World Bank. (1995). Harnessing information for development: World Bank Group vision and strategy. World Bank/International Bank for Reconstruction and Development, Washington DC. Retrieved 12 September, 2008, from http://www.worldbank.org.

(Edited by Ruby and Chris) 